\title{
University Lecturers' Professional Empowerment and Turnover in Uganda
}

\author{
Livingstone Ddungu ${ }^{1}$ \\ ${ }^{1}$ Makerere University [E-mail: livingstonedunguddungu@yahoo.com]
}

\begin{abstract}
Many universities in Uganda are grappling with the challenge of academic staff turnover. While research conducted so far has established different factors explaining the problems of turnover, many of which have been addressed, this challenge has not been resolved. Hitherto, attention has not been paid to whether professional empowerment of the lecturers explains this phenomenon and whether it can help to curb it. Therefore, this study was conducted to analyse the level of professional empowerment provided to the lecturers and the way it relates to their turnover. Data was collected from 384 lecturers using a structured questionnaire, and analysed using the descriptive, Chi Square, correlation, and regression techniques. The findings were that the level of professional empowerment is low and that this has contributed to the lecturers' turnover. Hence, the paper urges university managers to promote the lecturers' professional empowerment.
\end{abstract}

Keywords: Academic staff; Retention; Human Resources Management.

\section{$1 \quad$ Introduction}

The increasing level of voluntary academic staff turnover is one of the main challenges facing universities in Uganda today. The number of lecturers leaving both public and private universities is increasing at a pace much higher than that of their replacement. For instance, 68 lecturers left Makerere University between 2008 and 2012 (Mubatsi-Asinja, 2012). Ten senior lecturers left Gulu University between 2010 and 2012 (Oyat \& Aleni, 2013). During the same period, 15 dons left Kampala International University (Edabu, 2013), 17 left Ndejje University (Kayongo, 2013), and 19 left Kyambogo University (Jaramogi, 2013). Over 26 lecturers left Mbarara University of Science and Technology (MUST) between September and October 2011 (Turyakira, 2013) 
While presenting a report to the Parliamentary Committee on Science and Technology, the Academic Registrar of MUST noted that, "The increasing trend of lecturers leaving... or giving up on teaching is worrying...brain-drain of trained personnel...has left...the university incapacitated...There is need to move fast and ensure retention of good lecturers....and [provision of] quality education" (Turyakira, 2013, p.1). Therefore, the need to mitigate voluntary turnover behaviour displayed by lecturers cannot be overemphasized. This is especially so when it is taken into account that lecturers are leaving the universities at a time when most of the universities have not even filled their staff establishment. For instance, Makerere University is supposed to have 2,491 academic staff members but the audit conducted by the office of the Auditor General found out that it had only 1,262 (51\%) (Mubatsi-Asinja, 2012). The staff establishment is only $70 \%$ filled in Gulu University, 55\% at MUST, $56 \%$ at Kyambogo University and $85 \%$ at Ndejje University (Asiimwe \& Steyn, 2013).

Several studies (e.g. Asiimwe \& Steyn, 2013; Jaramogi, 2013; Kayongo, 2013; Oyat \& Aleni, 2013; Ndagire, 2011; Katusiime-Muhwezi, 2010) have been conducted to establish the cause of the turnover. Review of these studies reveals that they attribute the problem to many factors. These include weaknesses in the universities' governance, ill-facilitated work environments, inadequate remuneration, and rising competition for the dons arising out of both mushrooming universities on the local scene and rapid internationalization of university education. Addressing the concerns raised by the studies cited above may be a step in the right direction, but may not offer a sustainable solution to the problem of turnover. Herzberg's Two Factor Theory suggests that factors like work conditions, remuneration, and corporate policies do not offer enough explanation for an organization's ability to mitigate employee turnover (Zeynep \& Huckman, 2008). This means a sustainable solution to the problem of turnover requires additional remedies. Beairsto and Ruohotie (2003) suggest that professional empowerment could prevent staff attrition because it equips employees with the psychological and technical capacity that improves their intrinsic motivation, commitment, engagement, interest and love for their jobs to the extent of not desiring to leave (Boglera \& Somech, 2004).

This study undertook to examine the applicability of this proposition to the problem of lecturers' turnover in universities in Uganda. The specific objectives of the study were to examine:

1. the perceived level of professional empowerment provided to the lecturers

2. the voluntary turnover behaviour displayed by the dons

3. whether there is a difference in the level of professional empowerment and voluntary turnover behaviour displayed by lecturers in private and public universities in Uganda, and 
4. the relationship between the level of provided professional empowerment and voluntary turnover behaviour displayed by the dons.

The measures used to meet these objectives were identified from the literature presented in the following sections.

\section{$2 \quad$ Related Literature}

\subsection{Professional Empowerment}

The concept of professional empowerment is derived from the general notion of empowerment (Ciulla, 2004). According to Fracaro (2006), the notion of empowerment comes from the term 'empower', which refers to the process of facilitating individuals to develop, gain or acquire power or the ability needed to influence what is happening around them. Empowerment is itself defined as a process of increasing the cognitive and emotional capacity of individuals to make choices and to transform the choices into desired actions and outcomes (The World Bank Group, 2011). This definition suggests that empowerment involves facilitating a person to develop both a thinking and feeling that he/she is able to make effective and efficient choices in the context of what is desired. Effective empowerment is that which is provided at a level that makes a person feel internally capable and externally competent (The Centre for Effective Philanthropy, 2012). The internal capability is felt in form of a person's sense or belief that he/she has the capacity to make valued decisions and to solve his/her own problems. This capability is externally displayed in form of competency involving practicing the knowledge, the information, the skills, the capabilities and other resources acquired during empowerment (Hayes, 2003). These definitions are general and do not indicate how the degree at which an employee such as a lecturer is empowered affects voluntary turnover behaviour. They are however useful in that they provide lenses through which the level of professional empowerment can be visualised and measured.

In fact, some scholars have used the rationale of the above definitions as a basis for defining professional empowerment as a process involving continuous improvement of a certified person's proficiency and effectiveness in making and implementing choices related to his/her job (Seidel \& Shavelson, 2007; Meirink, Meijer \& Verloop, 2007). They also define the level of empowerment as the degree to which this improvement takes place (Meirink et al., 2007). In the context of educational institutions like universities, the level of professional empowerment is reflected by the scale of efforts put in to design teachers' capacity enhancement policies and the degree to which these policies are implemented to create an environment that enables teachers to engage in 
activities that enhance their teaching, research and innovative abilities, skills, knowledge, expertise and attitude (OECD, 2009; Boglera \& Somech, 2004). Believing that the initial certification of teachers is only the beginning of professionalism, other scholars argue that the level of empowerment connotes the extent to which this professionalism is improved on a continuous (Baumert et al., 2005, 2010). However, these scholars fell short of elaborating how the provision of this knowledge affects staff turnover behaviour.

Professional empowerment is regarded as a process by which teachers are facilitated, particularly in terms of preparation for teaching, teaching, time management, and job innovativeness (Darling-Hammond, 2009). According to Boglera and Somech (2004), the essence of professional empowerment is to enable teachers release and utilize their experience, initiative, knowledge, and wisdom. The process involves actions and programmes which build teachers' capacity to improve their own proficiency and outcomes as well as the efficiency and effectiveness of their schools (Clement \& Vandenberghe, 2008). Such programmes include training of trainers through internal workshops, tutorials, case studies, seminars, and apprenticeships (Rivkin, Hanushek \& Kain, 2005). These observations describe how professional empowerment for teachers takes place, but they do not explain how it affects staff turnover. Moreover, they approach the capacity gained from empowerment as though it is one general concept, yet this is not the case.

According to Beairsto and Ruohotie (2003), professional empowerment has two dimensions: the psychological and technical. They defined psychological empowerment as a state of intrinsic motivation felt by an employee in terms of cognitive constructs which include meaning, competence, self-determination, and impact. They defined meaning as the degree to which the requirements of an employee's job match his/her individual beliefs, values, and behaviour. They defined self-determination as an employee's regulation of his/her actions based on choice and autonomy to decide on the initiation and continuation of work, effort, work methods, pace of work, and so on. They viewed impact as the extent to which an employee feels able and inclined to influence strategic, administrative, and operative results at work. These scholars defined competence as the ability and skill of an employee to perform his/her job. Employees' competence is empowered through on-job and off-job training and capacity enhancement programmes such as employee evaluation and feedback, long and short courses, workshops, seminars, apprenticeships, mentoring, tutorials, attitude shaping talks, case studies, and self-development initiatives like online and other professional learning activities (Sleegers, Bolhuis \& Geijsel, 2010; Supovitz, 2009; Meirink, Meijer \& Verloop, 2007; McLaughin $\&$ Talbert, 2006). Beairsto and Ruohotie (2003) noted that although these cognitive constructs improve an individual's orientation to work in a much more useful, committed, satisfied and engaged way, they tend to be neglected 
in the empowerment programmes of most organizations. This suggests that psychological empowerment can encourage employees to stay on rather than leave their jobs. However, the extent to which this empowerment is provided is low in most organizations. It is for this reason that the level of psychological empowerment given to lecturers in private and public universities of Uganda needed to be investigated following the universities' low retention levels.

Most organizations neglect psychological empowerment believing that it is enough to empower staff technically (Clarke \& Hollingsworth, 2002). They thereby concentrate on what they perceive as sufficient levels of employee empowerment provided in form of greater responsibility and commensurate autonomy, resources and rewards (Eurydice, 2008). Beairsto and Ruohotie (2003) have, however, observed that although technical forms of empowerment are necessary, they do not offer employees with adequate opportunities to feel psychologically empowered. These scholars observed further that when employees do not feel psychologically empowered, they cannot engage in empowered actions and work styles such as self-management and teamwork. Employees who are not psychologically empowered cannot make, implement, and do not feel accountable for any work-related decisions. It is not enough to empower employees by promoting their access to work-related information, giving material resources and rewards. Effective professional empowerment should combine the psychological and technical dimensions and should be extended by providing employees with adequate levels of job-meaning, knowledge, skills, work resources, authority, opportunity for self-determination and for feeling intrinsically responsible and accountable for the outcomes of their actions (Geijsel, Sleegers, Stoel \& Krüger, 2009). In fact, research has shown that educational institutions that promote this type of professional empowerment register high levels of staff retention (Hendriks et al., 2010; Fulton, Lee \& Yoon, 2009; The State Educational Technology Directors Association (SETDA), 2008). This is however, just an implication, which needs to be proved empirically; for it is based on research conducted about staff retention (not turnover) and in Europe, not in universities in Uganda.

\subsection{Staff Turnover Behaviour}

The concept of staff turnover behaviour delineates the manner in which employees leave and get replaced in an organization in a given period (Society for Human Resource Management, 2012). Typically, this concept connotes the way employees leave their jobs either voluntarily or involuntarily (Tett \& Meyer, 2006). Involuntary turnover behaviour takes place in form of forced resignations, interdictions, terminations, dismissals, forced leaves, nonrenewable or not renewed employment contracts, due retirement, incapacitating illnesses and death (Sullivan, 2003). Since this turnover behaviour is 
involuntary, it is not the concern of this paper. The concern of this paper is about voluntary turnover behaviour because it is the type with which universities in Uganda are grappling.

Voluntary turnover behaviour takes place in form of discretionary actions carried out by employees in form of deliberate staff resignations, prolonged or extra leave requests, absconding from duty, unexplained and prolonged absenteeism, and failed return-to-work discussions (Imran-Malik, Zaheer, Mehboob \& Khan, 2010; Lambert \& Hogan 2008; According to Zeynep and Huckman, 2008). Voluntary turnover behaviour is also reflected by its consequences such as incurring of unexpected staff replacement costs, extra workloads to the remaining staff members, overtime payments, missed deadlines, interruptions to the flow of work, higher levels of stress-related absence, low staff morale, declining staff productivity, and unsatisfactory services to customers (Shaw, 2010; Zeynep \& Huckman, 2008). This behaviour is further reflected by turnover intentions (Kyomuhendo, 2012). Thus, asking employees to indicate whether they have intentions to leave their organizations or not is one way of measuring the staff turnover behaviour. Indeed, employees with intentions to leave indicate that they will eventually leave (Tett \& Meyer, 2006). The intentions are expressed in form of buying and/or reading newspapers to find advertised jobs, making job applications to other organizations when still holding the current job, and making online and other enquiries about whether there are vacant posts in other organizations (Kyomuhendo, 2012). It has been observed that employees develop intentions to stay or leave an organization basing on various reasons ranging from personal reasons to those related to how they are treated by their organizations (Imran-Malik et al., 2010). This paper focuses on how organizations, particularly universities in Uganda, treat their academic employees in terms of professional empowerment.

\section{$3 \quad$ Methodology}

This paper is compiled from a study designed as a descriptive cross-sectional survey complimented by a correlational design and some aspects of a comparative research design. The descriptive cross-sectional was used to facilitate the collection of first-hand quantitative data in a short time using questionnaires administered to a relatively large population of lecturers selected from different institutions, which included private and public universities. The study population size, expected sample size, which was determined using Sloven's formula, and the actual sample size were as summarised in Table 1. 
Table 1: Population and Sample

\begin{tabular}{llllllllll} 
& \multicolumn{3}{c}{ Population* } & \multicolumn{3}{c}{ Sample } & \multicolumn{4}{c}{ Respondents } \\
Category & Public & Private & Total & Public & Private & Total & Public & Private & Total \\
\hline Universities & 7 & 24 & 31 & 4 & 12 & 16 & 4 & 12 & 16 \\
Lecturers & 3070 & 4606 & 7676 & 128 & 256 & 380 & 134 & 250 & 384 \\
\hline *Source: National Council for Higher Education & $(2010)$ & & & &
\end{tabular}

*Source: National Council for Higher Education (2010).

Universities were selected using simple random sampling to give each university an equal chance of participating in the study, since they all witnessed the problem of staff turnover. All the lecturers were selected using convenience sampling, a non-probability sampling technique that was deemed appropriate to facilitate their selection according to their availability, accessibility in their respective offices, and willingness to participate in the study. Data was collected using a structured questionnaire. A copy of this questionnaire was administered to each lecturer after seeking their consent. The questionnaire's Cronbach Alpha coefficient was 0.876, implying that its items were reliable since the Alpha was greater than 0.7, the minimum acceptable threshold (Amin, 2005). The data was analysed using descriptive, correlation, regression and Chi Square techniques.

\section{$4 \quad$ Findings}

The first objective was to establish the perceived level of professional empowerment provided to the lecturers. This objective was met by asking the lecturers to rank their level of professional empowerment. The ranking was done on a scale with five options: "Strongly agree", "Agree", "Neutral", "Disagree" and "Strongly Disagree". The findings are summarised in Table 1. 
Table 1: Level of Professional Empowerment provided to Lecturers

\begin{tabular}{|c|c|c|c|c|c|}
\hline Attributes & Dimensions & Indicators & $\mathrm{N}$ & Mean & SD \\
\hline \multirow[t]{9}{*}{ Technical } & Capacity & The university has policy for enhancing lecturers' professional capacity & 384 & 4.35 & .483 \\
\hline & & $\begin{array}{l}\text { The university is equipped with ICT facilities that lecturers can use to } \\
\text { become more knowledgeable about how to do their work better } \\
\text { The university has equipment which lecturers can use to enrich their }\end{array}$ & 384 & 4.22 & .486 \\
\hline & & ability to perform assigned work & 384 & 4.13 & .248 \\
\hline & & $\begin{array}{l}\text { The university has information centres like libraries from which lecturers } \\
\text { can learn how to improve their ability to work }\end{array}$ & 384 & 4.34 & .464 \\
\hline & Responsibility & The university has a system of increasing the teaching workload assigned & & & \\
\hline & & $\begin{array}{l}\text { to lecturers } \\
\text { The university has a system of increasing the non-teaching workload } \\
\text { assigned to lecturers }\end{array}$ & 384 & 4.14 & .913 \\
\hline & Autonomy & $\begin{array}{l}\text { The university gives lecturers the autonomy that is commensurate to the } \\
\text { work assigned to them }\end{array}$ & 384 & 3.74 & .606 \\
\hline & Rewards & The university remunerates lecturers for doing assigned work & 384 & 3.56 & .911 \\
\hline & & $\begin{array}{l}\text { The university extends non-financial rewards to lecturers for purposes of } \\
\text { encouraging them to feel motivated to do assigned work }\end{array}$ & 384 & 2.21 & .834 \\
\hline \multirow[t]{5}{*}{ Psychological } & Competence & The university organizes capacity enhancement workshops for lecturers. & 384 & 4.35 & .031 \\
\hline & & The university organizes capacity enhancement seminars for lecturers. & 384 & 3.53 & .868 \\
\hline & & $\begin{array}{l}\text { The university organizes talks for shaping lecturers' professional attitude } \\
\text { The university sponsors lecturers interested in pursuing further }\end{array}$ & 384 & 2.04 & .089 \\
\hline & & $\begin{array}{l}\text { professional training } \\
\text { The university has a system of using long-time serving lecturers to }\end{array}$ & 384 & 4.32 & .871 \\
\hline & & mentor less experienced lecturers & 4 & 41 & 1 \\
\hline
\end{tabular}




\begin{tabular}{|c|c|c|c|c|c|}
\hline Attributes & Dimensions & Indicators & $\mathrm{N}$ & Mean & SD \\
\hline & \multirow{5}{*}{ Meaning } & $\begin{array}{l}\text { The university evaluates lecturers for purposes of identifying how to help } \\
\text { them improve their competency }\end{array}$ & 384 & 4.04 & .993 \\
\hline & & The university gives lecturers feedback on how they can teach better & 384 & 4.14 & .863 \\
\hline & & $\begin{array}{l}\text { The university's timetable allows lecturers to have time for self- } \\
\text { development through individually initiated online or other professional } \\
\text { learning activities. }\end{array}$ & 384 & 4.17 & .767 \\
\hline & & $\begin{array}{l}\text { The university has a system that encourages lecturers to align their } \\
\text { personal values with the requirements of their jobs }\end{array}$ & 384 & 1.13 & .601 \\
\hline & & $\begin{array}{l}\text { The university ensures that lecturers' beliefs are aligned their personal } \\
\text { values and beliefs with the requirements of their jobs }\end{array}$ & 384 & 1.13 & .041 \\
\hline & \multirow[t]{4}{*}{$\begin{array}{l}\text { Self- } \\
\text { determination }\end{array}$} & $\begin{array}{l}\text { The university gives lecturers an opportunity to make choices regarding } \\
\text { how they can best do their jobs }\end{array}$ & 384 & 2.13 & .909 \\
\hline & & The university gives lecturers an opportunity to exercise autonomy & 384 & 1.35 & .982 \\
\hline & & I feel free do what I think is best for the university & 384 & 2.16 & .942 \\
\hline & & $\begin{array}{l}\text { The university has made me feel that I can work effectively without } \\
\text { supervision }\end{array}$ & 384 & 1.35 & .928 \\
\hline & \multirow[t]{2}{*}{ Impact } & $\begin{array}{l}\text { I feel free to advise the university's management about how my job can } \\
\text { be carried out to yield better results for the university }\end{array}$ & 384 & 2.16 & .956 \\
\hline & & decisions & 384 & 2.43 & .766 \\
\hline
\end{tabular}

Scale: $1=$ Strongly Disagree $\quad$ 2=Disagree 3=Neutral $4=$ Agree 5=Strongly Agree 
The standard deviations in Table 1 were all numerically small, suggesting that the responses obtained from lecturers as individuals did not deviate much from their average response pattern as reflected in the mean values. A careful look at these means indicates that they were close to ' 4 ', ' 2 ' or ' 1 '. While ' 5 ' stood for high levels of empowerment, ' 4 ' meant low and therefore unsatisfactory levels of empowerment, and both ' 1 ' and ' 2 ' meant no professional empowerment. These mean values in Table 1 indicate therefore that professional empowerment provided to the lecturers varied, on average, between no empowered and unsatisfactory levels of empowerment. A closer scrutiny of the mean values reveals that those that were close to ' 4 ' corresponded to the indicators of technical empowerment and competence. The mean values that corresponded to the indicators of meaning, self-determination and impact were close to ' 2 ' or ' 1 '. The findings suggest therefore the professional empowerment the lecturers were given in terms of remuneration was low and unsatisfactory (Mean $=3.56$, Std. = .911). They felt un-empowered with respect to the non-financial rewards $($ Mean $=2.21$, Std. $=.834)$. Lecturers were not provided with psychological professional empowerment. They, for instance, felt not empowered in terms of developing meaning concerning how their personal values were aligned with the requirements of their jobs $($ Mean $=1.13$, Std. $=.601)$. lecturers further felt un-empowered in terms of self-determination such that which takes the form of freedom to do what they thought was best for the university (Mean $=2.16$, Std. $=.942$ ). They also felt not empowered in terms of causing impact like that which would occur in form of, say, being free to suggest ideas that could influence their university's strategic decisions.

The second objective was to establish the voluntary turnover behaviour displayed by lecturers in public and private universities in Uganda. The findings are shown in Table 2. 
Table 2: Description of Voluntary Turnover Behaviour Displayed by Lecturers in Public and Private Universities in Uganda Academic staff turnover behaviour

N Mean Std. Dimensions Specific indicators

Turnover actions At least one member of the academic staff resigned deliberately in the past 12 months

I know of at least one lecturer who left preferring early retirement

I am aware of a lecturer who absconded from duty

$\begin{array}{lll}384 & 4.53 \quad .039\end{array}$

I am aware of

$\begin{array}{lll}384 & 4.59 & 877\end{array}$

work without any explanation

$\begin{array}{lll}384 & 4.62 \quad .809\end{array}$

I am aware of return-to-work discussions that failed to bring back the involved lecturer

Turnover

We have been experiencing interruptions as a result of some lecturers leaving willingly to take up jobs in other organizations

I am stressed because of doing extra workload as a result of some lecturers leaving the university

Deadlines are now missed because some lecturers left

I get overtime payments as a result of being asked to stand in for a lecturer who left.

I know of at least one lecturer who was replaced a few months ago

I feel demoralized because my colleagues have left

My productivity has declined because my colleagues left

Turnover intentions I know of a lecturer who reads newspapers to find advertised jobs

I am aware of at least one lecturer who is making job applications to other organizations

I know of at least one lecturer who makes enquiries about whether there are vacant 
The magnitudes of standard deviations in Table 2 were small and therefore, pointing to low dispersion in the sample. Therefore, responses obtained from individual respondents showed no much difference from the average response pattern as depicted by the mean values. Most of these values were close to ' 4 ' or ' 5 '. The findings therefore, show that lecturers' display of voluntary turnover behaviour varied, on average, between low and high levels. An analytical look at the mean values reveals that those which corresponded to indicators of turnover actions and intentions were close to ' 5 '. This suggests that the universities witnessed high levels of voluntary staff turnover behaviour that occurs in form of turnover actions and intentions. The mean values corresponding to indicators of turnover consequences were close to ' 4 ', except those corresponding to the stress felt by lecturers because of doing extra workload resulting from some of their colleagues leaving $($ mean $=4.66$, Std. $=$ .667 ) and to replacement of lecturers (mean $=4.74$, Std. $=.903$ ). This implies that the selected universities witnessed a low level of turnover consequences. The exceptions were the stress felt by lecturers and the replacement of lecturers whose level was high.

The third objective was to establish whether there was a significant difference in the level of professional empowerment and voluntary turnover behaviour displayed by lecturers in private and public universities. This difference was established using the Chi Square method after reducing the various indicators of the two variables into their significant measures using factor analysis. The findings are summarized in Table 3 . 
Table 3: Difference in level of professional empowerment and voluntary staff turnover behaviour between Uganda's public and private universities

\begin{tabular}{|c|c|c|c|c|c|}
\hline Variables & Proprietorship & $\mathrm{N}$ & Mean & $x^{2}$ wes & Sig. \\
\hline \multirow[t]{2}{*}{ Technical empowerment } & Public & 134 & 4.36 & 1.483 & .309 \\
\hline & Private & 250 & 4.23 & & \\
\hline \multirow[t]{2}{*}{ Resources } & Public & 134 & 4.36 & 1.758 & .231 \\
\hline & Private & 250 & 4.06 & & \\
\hline \multirow[t]{2}{*}{ Responsibility } & Public & 134 & 4.34 & 0.868 & .493 \\
\hline & Private & 250 & 4.13 & & \\
\hline \multirow[t]{2}{*}{ Autonomy } & Public & 134 & 4.01 & 1.876 & .201 \\
\hline & Private & 250 & 4.34 & & \\
\hline \multirow[t]{2}{*}{ Rewards } & Public & 134 & 4.30 & 1.911 & .169 \\
\hline & Private & 250 & 4.18 & & \\
\hline \multirow{2}{*}{ Psychological empowerment } & Public & 134 & 1.31 & .993 & .483 \\
\hline & Private & 250 & 1.03 & & \\
\hline \multirow[t]{2}{*}{ Meaning } & Public & 134 & 2.42 & .601 & .763 \\
\hline & Private & 250 & 2.44 & & \\
\hline \multirow[t]{2}{*}{ Competence } & Public & 134 & 4.04 & .909 & .473 \\
\hline & Private & 250 & 4.14 & & \\
\hline \multirow[t]{2}{*}{ Self-determination } & Public & 134 & 2.42 & 1.942 & .153 \\
\hline & Private & 250 & 2.06 & & \\
\hline \multirow[t]{2}{*}{ Impact } & Public & 134 & 1.06 & 1.956 & .160 \\
\hline & Private & 250 & 1.23 & & \\
\hline \multirow{2}{*}{$\begin{array}{l}\text { Level of professional } \\
\text { empowerment }\end{array}$} & Public & 134 & 3.51 & 1.766 & .183 \\
\hline & Private & 250 & 3.53 & & \\
\hline \multirow[t]{2}{*}{ Turnover actions } & Public & 134 & 4.72 & 3.919 & .006 \\
\hline & Private & 250 & 4.39 & & \\
\hline \multirow[t]{2}{*}{ Turnover intentions } & Public & 134 & 4.68 & 3.337 & .007 \\
\hline & Private & 250 & 4.06 & & \\
\hline \multirow[t]{2}{*}{ Turnover consequences } & Public & 134 & 4.43 & 1.109 & .367 \\
\hline & Private & 250 & 4.39 & & \\
\hline \multirow{2}{*}{$\begin{array}{l}\text { Displayed staff turnover } \\
\text { behaviour }\end{array}$} & Public & 134 & 4.63 & 3.284 & .009 \\
\hline & Private & 250 & 4.15 & & \\
\hline
\end{tabular}

From Table 3, the observed Chi Square values corresponding to the level of professional empowerment $\left(X_{0 b s}^{z}=1.766\right.$, Sig. $\left.=.183>.05\right)$ was not significant yet the Chi Square value corresponding to displayed staff turnover behaviour $\left(\chi_{0 b s}^{z}=3.284\right.$, Sig. $\left.=.009<.05\right)$ was significant. These findings imply that while there was no significant difference in the level of professional empowerment provided by private and public universities, there was a significant difference in the turnover behaviour witnessed in the two categories of universities. The 
mean values corresponding to the level of staff turnover behaviour indicate that the difference favoured private universities. Indeed, the last row of Table 3 indicates that the level of displaying staff turnover behaviour was high in public universities (mean $=4.63$ ) and low in private universities (mean $=4.15)$. Further scrutiny of the Chi Square values in Table 3 indicates that the value corresponding to turnover intentions $\left(x_{0 b s}^{z}=3.337\right.$, Sig. $\left.=.007<.05\right)$ and turnover actions $\left(\chi_{0 b y}^{2 z}=3.919\right.$, Sig. $\left.=.006<.05\right)$ were significant. This suggests that lecturers in public universities displayed more turnover intentions and actions, thereby causing the significant difference in the overall level of staff turnover behaviour demonstrated in the two types of universities. The mean values show that lecturers in public universities reported higher turnover intentions (mean $=4.68)$ yet their counterparts in private universities reported a low level of these intentions (mean $=4.06$ ).

The fourth objective of the paper was to analyse the relationship between the level of professional empowerment provided and voluntary turnover. This relationship was established using the Pearson Correlation coefficient method and the findings are presented in Table 4.

Table 4: Relationship between level of professional empowerment and voluntary academic staff turnover behaviour

\begin{tabular}{|c|c|c|c|c|c|c|c|}
\hline Variables & 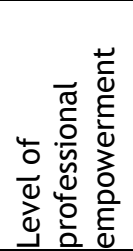 & 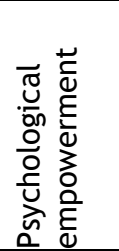 & 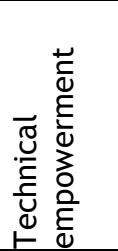 & 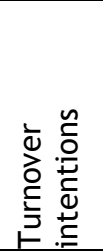 & 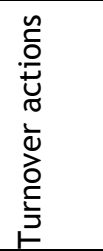 & 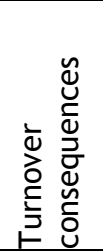 & 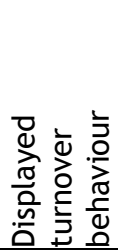 \\
\hline $\begin{array}{l}\text { Level of professional } \\
\text { empowerment }\end{array}$ & 1 & & & & & & \\
\hline $\begin{array}{l}\text { Psychological } \\
\text { empowerment } \\
\text { Technical }\end{array}$ & $.989^{* *}$ & 1 & & & & & \\
\hline empowerment & $.919^{* *}$ & $.636^{* *}$ & 1 & & & & \\
\hline Turnover intentions & $-.743^{* *}$ & $-.751^{* *}$ & $-.561^{* *}$ & 1 & & & \\
\hline Turnover actions & $-.634^{* *}$ & $-.764^{* *}$ & $-.587^{* *}$ & $.899^{* *}$ & 1 & & \\
\hline $\begin{array}{l}\text { Turnover consequences } \\
\text { Displaved turnover }\end{array}$ & $-.503^{* *}$ & $-.510^{* *}$ & $-.506^{* *}$ & $.898^{* *}$ & $.898^{* *}$ & 1 & \\
\hline behaviour & $-.753^{* *}$ & $-.733^{* *}$ & $-.655^{* *}$ & $.967^{* *}$ & $.977^{* *}$ & $.936^{* *}$ & 1 \\
\hline
\end{tabular}

** Correlation coefficient $(r)$ is significant at the .01 level (2-tailed).

Table 4 shows that the correlation coefficient between the level of professional empowerment and the displayed staff turnover behaviour $(\mathrm{r}=-.753)$ was negative and significant at the .01 level of significance. There was therefore a strong, negative and significant relationship between the level of professional empowerment and level of staff turnover. After establishing this relationship, it 
was deemed necessary to determine whether the relationship was predictive. This was carried out using linear regression analysis. Findings are summarized in Table 5.

Table 5: Prediction of level of academic staff turnover behaviour by the level of professional empowerment

\begin{tabular}{|c|c|c|c|c|c|c|c|c|}
\hline \multirow[b]{2}{*}{$\begin{array}{l}\text { Predictor } \\
\text { (Level of } \\
\text { professional } \\
\text { empowerment) }\end{array}$} & \multicolumn{8}{|c|}{ Predicted Statistics on the Level of staff turnover } \\
\hline & $\begin{array}{l}\text { Std Beta } \\
\text { Error }\end{array}$ & $\mathrm{t}$ & Sig. & $\begin{array}{l}\text { R. } \\
\text { Square }\end{array}$ & $\begin{array}{l}\text { Adjusted } \\
\text { R-Square }\end{array}$ & & Sig. & $\begin{array}{l}\text { Std. } \\
\text { Error of } \\
\text { the } \\
\text { Estimate }\end{array}$ \\
\hline $\begin{array}{l}\text { (Constant) } \\
\text { Psychological } \\
\text { empowerment }\end{array}$ & $\begin{array}{ll}.135 & \\
.026 & -.537\end{array}$ & $\begin{array}{l}12.533 \\
-7.833\end{array}$ & $\begin{array}{l}.000 \\
.000\end{array}$ & .871 & .867 & 197.355 & .000 & .326 \\
\hline $\begin{array}{l}\text { Technical } \\
\text { empowerment }\end{array}$ & .023 & -3.555 & .003 & & & & & \\
\hline
\end{tabular}

From Table 5, the standard errors and of the overall error of estimate were numerically very small, implying that the linear regression method was largely suitable to estimate the model. The predicted statistics indicate that the level of professional empowerment provided to lecturers predicted staff turnover faced by the selected universities by $86.7 \%$ (Adjusted R-Square $=.867, \mathrm{~F}=197.355$, Sig. $=.000<.01)$. The beta coefficients, their corresponding t-values and levels of significance reveal that psychological empowerment $($ Beta $=-.537, \mathrm{t}=-$ 7.833, Sig. $=.000<.01)$ and technical empowerment $($ Beta $=-.429, \mathrm{t}=-3.555$, Sig. $=.003<.01)$ were both significant and negative predictors of staff turnover. The magnitudes of the beta coefficients show that psychological empowerment negatively predicted $53.7 \%$ of staff turnover and was therefore a more critical predictor when compared to technical empowerment, which predicted $42.9 \%$.

\section{Discussion}

Findings indicate that holding other factors constant, the level of professional empowerment provided to lecturers can reduce the turnover behaviour displayed by lecturers in Uganda's public and private universities by $86.7 \%$ (Table 5). These findings suggest that professional empowerment can help mitigate the academic staff turnover behaviour that is threatening to incapacitate the ability of Uganda's public and private universities to provide the desired quality of education. There is thus need to promote this empowerment in the universities. This need cannot be ignored in the light of the 
fact that all the universities still grappling with high levels of lecturers' display of turnover behaviour. Indeed, the levels at which lecturers displayed turnover intentions and actions were high (Table 2), especially in public universities (Table 3). Even the turnover consequences like frequent staff replacements and lecturers feeling stressed because of doing extra workload added when their colleagues leave were also still high in the universities (Table 2). Lowering these intentions, actions and consequences makes it imperative for the universities to promote the professional empowerment of their dons.

Such promotion is needed owing to the fact that the level at which all the selected private and public universities provided professional empowerment to their lecturers varied between no empowerment at all to low and therefore unsatisfactory empowerment (Table 1). The universities provided lecturers with low and unsatisfactory teaching resources, responsibility, autonomy, rewards and competence. In addition to being unsatisfactory, the empowerment given focused on mainly the technical dimension. The psychological empowerment provided focused on competence alone. The provision of psychological empowerment in the cognitive constructs of meaning, self-determination and impact was negligible. The findings therefore, support the observations made by Clarke and Hollingsworth (2002) and Eurydice (2008) that most organizations neglect the psychological empowerment of their employees and concentrate on providing technical empowerment.

However, as Beairsto and Ruohotie (2003) warned, when lecturers are not psychologically empowered, they may not engage in empowered actions, even when they are technically empowered. Based on Boglera and Somech (2004) argument, the failure to engage in empowered actions implies that the lecturers do not display intrinsic motivation, commitment, engagement, interest and love for their jobs. This state of affairs makes it easy for them to develop a desire to leave their jobs. The situation becomes worse when the level of provided technical empowerment is even low and therefore, not sufficient as the case is in the universities studied. This effectively suggests that efforts to promote the professional empowerment of lecturers need to improve the technical dimension while at the same time putting emphasis on psychological empowerment. Therefore, it is recommended that the managers of Uganda's universities should provide lecturers with psychological empowerment in all the cognitive constructs of job meaning, self-determination and felt impact on the universities' strategic direction. They can promote these empowerment by providing lecturers with freedom to think strategically and innovatively for the university, and to make creative contributions to the development of the university. 


\section{References}

Amin, M.E. (2005). Social science research: Conception, methodology and analysis. Kampala: Makerere University Printery

Asiimwe, S., \& Steyn, G.M. (2013). Obstacles hindering the effective governance of universities in Uganda. [Online]. Retrieved on December 3, 2013 from http://www.krepublishers .com/02-Journals/JSS/JSS-34-0-000-13Web/JSS-34-1-000-13-Abst-PDF/JSS-34-1-017-13-1423-Steyn-G-M/JSS34-1-017-13-1423-Steyn-G-M-Tx\%5B3\%5D.pmd.pdf

Baumert, J., Blum, W., Brunner, M., Jordan, A., Klusmann, U., Krauss, S., Kunter, M., Neubrand, M. and Tsai, Y.M. (2005). Professional Knowledge of Teachers, Cognitively Activating Instruction, and the Development of Mathematical Competence (COACTIV). Presentation at the OECD workshop of the Networks $A$ and $C$ on Teaching and Learning, Reykjavik, October

Baumert, J., Blum, W., Brunner, M., Jordan, A., Klusmann, U., Krauss, S., Kunter, M., Neubrand, M. \& Tsai, Y-M. (2010). Professional knowledge of teachers, cognitively activating instruction, and the development of mathematical competence (COACTIV), Presentation at the OECD workshop of the Networks $A$ and $C$ on Teaching and Learning. Reykjavik, October.

Beairsto, B., \& Ruohotie, P. (2003). Empowering professionals as lifelong learners In B. Beairsto, M. Klein \& P. Ruohotie (Eds.) Professional learning and leadership. Tampere, Finland: University of Tampere.

Boglera, R., \& Somech, A. (2004). Influence of teacher empowerment on teachers' organizational commitment, professional commitment and organizational citizenship behaviour in schools. Teaching and Teacher Education, 20: 277-289. [Online]. Retrieved on December 3, 2013 from www.elsevier.com/locate/tate.

Ciulla, J.B. (2004). Leadership and the Problem of Bogus Empowerment, In Ciulla, Joanne B., Ethics, the heart of leadership (2 ed.), Greenwood Publishing Group.

Clarke, D.J., \& Hollingsworth, H. (2002). Elaborating a model of teacher professional growth. Teaching and Teacher Education, 18: 947-967.

Clement, M. \& Vandenberghe, R. (2008). Teachers' professional development: A solitary or collegial (ad) venture? Teaching and Teacher Education, 16: 81-101.

Collis, J., \& Hussey, R. (2003). Business research - a practical guide for undergraduate and postgraduate students. 2nd Ed. Great Britain: Palgrave Macmillan. 
Darling-Hammond, L. (2009). Teacher quality and student achievement: A review of state policy evidence. Seattle, WA: Centre for the Study of Teaching and Policy, University of Washington.

Edabu, P. (2013). Motivation tools and work productivity of academic staff in private universities in central Uganda. Kampala International University: Unpublished $\mathrm{PhD}$ Dissertation.

Eurydice. (2008). Levels of autonomy and responsibilities of teachers in Europe. Brussels: Eurydice.

Fracaro, K.E. (2006). The real meaning of empowerment. [Online]. Retrieved on December 3, 2013 from http://www.ncmahq.org/files/articles/18ed7_cm_mar06p4.pdf

Fulton, K. Lee, C, Yoon, I. (2009). Induction into learning communities. National Commission on Teaching and America's Future. Washington, DC.

Geijsel, F., Sleegers, P., Stoel, R. \& Krüger, M. (2009). The effect of teacher psychological, school organizational and leadership factors on teachers' professional learning in Dutch Schools. The Elementary School Journal, 109 (4): 406-427.

Hayes, J. (2003). Employee empowerment: Commerce bank and cast-fab technologies. Emporia State University: School of Business, January.

Hendriks, M., Luyten, H., Scheerens, J., Sleegers, P., \& Rien, S. (2010). Teachers' professional development: Europe in international comparison: An analysis of teachers' professional development based on the OECD's teaching and learning international survey (TALIS). Office for official publications of the European Union. Retrieved December 7, 2013 from http://europa.eu

Imran-Malik, M., Zaheer, A., Mehboob, A., \& Khan, A. (2010). Developing and testing a model of burnout at work and turnover intensions among doctors in Pakistan. International Journal of Business and Management, 10: 35-50. [Online]. Retrieved on December 7, 2013 from www.ccsenet.org/ijbm

Jaramogi, P. (2013). Kyambogo varsity staff demand 300\% pay-rise. [Online]. Retrieved on December 3, 2013 from http://www.newvision.co.ug/mobile/detail.aspx?newsid=19051 \&catid=6

Katusiime-Muhwezi, M. (2010). Recruitment, selection procedures and employee retention in private universities in Uganda: A case study of Kampala International University. Makerere University: Unpublished Master of Org. Psycho thesis.

Kayongo, P. (2013). An analysis of the key factors determining the levels of motivation of the academic staff of Ndejje University. Brookes Oxford University: Unpublished B.Sc. Acc. Thesis. 
Kyomuhendo, I.B. (2012). Assessing employee satisfaction strategies on staff retention: The case of Uganda Revenue Authority. Uganda Management Institute (Unpublished MBA dissertation)

Lambert, E.N., \& Hogan, L. (2008). The importance of job satisfaction and organizational commitment in shaping turnover intent: A test of a causal model. Criminal Justice Review. 1: 96 - 118.

McLaughin, M.W., \& Talbert, J.E. (2006). Building school-based teacher learning and communities. Professional strategies to improve student achievement. New York: Teachers College Press.

Meirink, J., Meijer, P. \& Verloop, N. (2007). A closer look at teachers' individual learning in collaborative settings. Teachers and Teaching: Theory and Practice, 13(2): 145-164.

Mubatsi-Asinja, H. (2012). Makerere losing staff over low pay [Online]. Retrieved on December 5, 2013 from http://www.independent.co.ug/news/news-analysis/5863

Ndagire, R. (2011). Remuneration and job satisfaction of academic staff in School of Education, Makerere University: M. Ed diss., Makerere University.

Oyat, C., \& Aleni, F.G. (2013). Work environment and labour turnover in public universities in Uganda: The case of Gulu University. Prime Journal of Business Administration and Management, 3(6), 1070-1075. [Online]. Retrieved on December 3, 2013 from www. primejournal.org/BAMhttp://www.primejournal.org/BAM/pdf/2013/jun/Oya t\%20and\%20Aleni.pdf

Rivkin, S.G., Hanushek, E.A., \& Kain, J.F. (2005). Teacher, schools, and academic achievement. Econometrica, 73 (2), 417-458.

Seidel, T., \& Shavelson, R.J. (2007). Teaching effectiveness research in the past decade: the role of theory and research design in disentangling metaanalysis results. Review of Educational Research, 77(4): 454-499.

Shaw, J.D. (2010). Turnover rates and organizational performance: Review, critique, and research agenda. Organizational Psychological Review. [Online]. Retrieved on December 7, 2013 from http://opr.sagepub.com/content/1/3/187.abstract

Sleegers, P., Bolhuis, S. \& Geijsel, F. (2010). School improvement within a knowledge economy: Fostering professional learning from a multidimensional perspective. International Journal of Educational Administration, 3 (5): 27-54.

Society for Human Resource Management. (2012). SHRM human capital benchmarking report 2011-2012. Alexandria, VA: SHRM.

Sullivan, J. (2003). The right way to measure turnover. [Online]. Retrieved on December 7, 2013 from http://www.ere.net/2003/10/06/the-right-way-tomeasure-turnover/ 
Supovitz, J.A., (2009). Developing communities of instructional practice. Teachers College Record, 104 (2): 127-146.

Tamale, G.D. (2007). Reward management and employee job performance institutions of higher learning using Uganda Christian University as a case study. Makerere University: Unpublished M. Ed dissertation.

Tett, R., \& Meyer, J. (2006). Job satisfaction, organizational commitment, turnover intention, and turnover: Path analyses based on meta-analytic Findings. Personal Psychology, 46: 259 - 293.

The Centre for Effective Philanthropy (2012). Employee empowerment: The key to foundation staff satisfaction. [Online]. Retrieved on December 6, 2013 from http://www.commonwealth fund.org/aboutus/ /media/Files/About $\% 20 U$ s/The $\% 20$ Key\%20to\%20Foundation $\% 20$ Staff $\%$ 20Satisfaction\%20Report\%20122012.pdf

The State Educational Technology Directors Association (SETDA) (2008). Empowering teachers: A professional and collaborative approach. [Online]. Retrieved on December 3, 2013 from www.setda.org.

The World Bank Group (2011). Empowerment. [Online]. Retrieved on December 3, 2013 from http://web.worldbank.org/wbsite/external/topics/extpoverty/extempowerment /0,,contentMDK:20245753 pagePK:210058 piPK:210062 theSitePK:4864 11,00.html

Turyakira, F. (2013). Mbarara University lecturers' exodus shocks MPs. Retrieved on December 3, 2013 from http://www.newvision.co.ug/mobile/Detail.aspx ?NewsID=19044\&CatID=6

Zeynep T., \& Huckman, R.S. (2008). Managing the impact of employee turnover on performance: the role of process conformance. Organization Science, 1(1): 56-68. [Online]. Retrieved on December 7, 2013 from http://www.people.hbs.edu/rhuckman/ton_h uckman.pdf. 